\title{
GLOBAL-DETECTOR: KNOWLEDGE-BASED ANALYSIS AND DIAGNOSIS OF ECONOMICAL PERFORMANCE ON DAIRY FARMS
}

\author{
Wil H.G.J. Hennen \& D.W. de Hoop \\ Agricultural Economics Research Institute \\ Section of Animal Husbandry \\ P.O.B. 29703, 2502 LS Den Haag, Holland
}

\begin{abstract}
The linancial performance of a farm is nowadays more dependent on the farmer's technical knowledge and management skills. To support management, microcumputer programs can be used.

The Agricultural Economics Rescarch Institute (LE) developed the knowledge-based computer system GLOBALDETECTOR for globally analysing cconomical and tochnical bookkeeping-data and to give advice for improvement This system, which softwarc is programmed in the languge muLISP, covers all retums and variable costs. For analysing the data, farm-adjusted standards are used. The acquisition and presentation of knowledge for the diagnosis of performance is done by a method (IMAGINE) which is developed especially for this reseanch.

GLOBAL-DETECTOR supports decision-making. In this perspective, the extensive explanation-facilities possessed by the system are crucial. First experiences with the system seem positive. Although farmer's individuai whishes and demands cannot be fuifilled casily with computer systems, GLOBAL-DETECTOR may be used on a large scale on account of the Mexibility and user-friendliness.
\end{abstract}

\section{INTRODUCTION}

Due to the milk quota system which is currently applied in the EC, the farmer's point of view has changed from increasing the scale of the farm (by strategic decisions), to more attention of lowering production costs (Poppe, 1986). Tactical decisions gain growing interest in this new situation. The financial performance of a farm is nowadays more dependent on the farmer's technical knowledge and management skills (Brand et al., 1986). In this perspective, it can be noticed that farmers aim at milking their full quota at the lowest possible cost by keeping an eye upon the total return- and cost-image (De Hoop et al., 1988).

De Haan (1991) compared two groups of dairy farms with the same area of land (about 37 hectare), number of cows (about 100) and milk production (about $6800 \mathrm{~kg}$ per cow). The first group of 40 farms (out of 283 random selected Dutch farms) had the highest gross-margin (total returns minus total variable costs) of about 340,000 Dutch guilders per farm. This group can be considered as the "best" fifteen percent of farms. The average gross-margin of the second group 
which consisted of 43 farms with a low gross-margin, was about $25 \%$ lower than the first. This difference of more than 100,000 Dutch guilders indicates for a great part distinct levels of management. According to King and Sonka (1988), farm management is the process by which decisions about allocating a farm's resources to meet desired ends are analyzed, made and implemented. Thorough studies on Dutch arable farms done by Zachariasse (1974) and on Dutch horticulture farms done by Alleblas (1988), showed that farm-results depend on management. Differences in management on dairy farms were also found in literature (e.g. Roep et al., 1991; De Hoop et al., 1988).

The main activity of a manager is decision making (Zachariasse, 1990b). Prerequisites for good decisions are not only information, but also creativity and decision power. However, information is the key element in the decision making process (Zachariasse, 1990b; Batte et al., 1990; Morahan et al., 1989).

Good managerial decisions need professional analysis of the available data (e.g. farm-data from bookkeeping) to yield the necessary information. But it mostly lacks good performance figures and good farm comparison (De Hoop et al., 1988). Party therefore, the use of accounting-data has not been very popular among farmers, although the need and demand for information will grow (Poppe, 1991a). This increase is due to changes in the farm's environment (e.g. King and Sonka, 1988), which makes the decision making process increasingly complex, resulting in a farmer's necessity for good information systems (Harsh et al., 1990).

The reports from external organisations display numerous data, but there is mostly a lacking of a thorough analysis from all these data (De Hoop et al., 1988). From this it is obvious that the farmer all by himself' has difficulties in analysing and drawing conclusions from the report. McGrann et al. (1989) note therefore: "Economics and finance are areas where expertise is often limited, leading to inadequate use of data and analysis tools by producers, lenders and educators. Expert systems offer a significant delivery technology.".

Since advances in computer hardware and software have increased the potential for effective computer-based support of farm management decisions (King et al., 1990), there are opportunities to bring data analysis and interpretation to microcomputer programs (McGrann et al., 1989). A number of these programs concern the financial structure of the farm. McGrann et al. give a description of the Agricultural Financial Analysis Expert System (AFAES), which includes software to make analysis summaries, graphic presentations of the analysis and a diagnostic analysis of the financial statement data. Dobbins and King (1988) show how the

'Only for the authors' convenlence, the farmer, expert, user, etc. will he assumed to be male. 
reports from the FINANX program (developed at the University of Minnesota) were interpreted by experts whose protocols provided the structure of an expert systems' knowledge-base.

Longchamp et al. (1990) give a description of ANFI: an expert system for financial analysis. This system may give the farmer a good idea about the way the farm is managed. The expert system FinARS, as is described by Boggess et al. (1989), supplies from a minimum dataset a "quick and easy" evaluation of the financial health of a farm business and "... it can be used as a diagnostic tool for farmers (...) to provide an initial interpretation of their firm's financial situation, diagnose its potential problems, and furnish suggested alternatives for improving the firm's financial situation". Philips and Harsh (1987) have developed an expert system similar to FinARS for analysing and interpreting the financial condition of a dairy farm. According to Dobbins (1988), diagnostic analysis provides the managers the information that will allow them to improve the performance.

A preliminary investigation of the Agricultural Economics Research Institute (LED) proved to have a beneficial impact of knowledge-based computer systems on management support for one detailed economic function (Hennen, 1989 and Breé and Hennen, 1989). However, "For a good analysis of the whole farm, data from many functions have to be used together." (Breé and Hennen, 1989). In order to support the dairy management covering all returns and variable costs and thereby improving the economic performance, an expert system (GLOBAL-DETECTOR) has been developed for globally analysing economical and technical bookkeeping-data. The analysis may be followed by a great number of graphical presentations, a "quick and easy" diagnosis of the strong and weak aspects of the management, and a presentation of possible ways for improving the economical performance. The goal of this paper is to describe and discuss GLOBAL-DETECTOR. A new method for knowledge acquisition will be of special interest. The scope of GLOBAL-DETECTOR will cover all aspects of gross-margin; fixed costs will be included later. The farmer's concern is the returns and variable costs, whereas the long-term decisions will only occur incidentally (De Hoop et al., 1988). The internal management of dairy farms is primarily focussed on efficient production, expressed in the gross-margin (Zachariasse, 1990a). Zachariasse observes that decisions concerning production are not only numerous, but they are also difficult to transfer to others. This is due to the complex circumstances in which these decisions take place. Because production is closer to the daily interest of the farmer and has an important impact on the financial results, the analysis and diagnosis of the financial structure of the farm (likewise above mentioned expert systems ASEAS and FinARS) has provisionally been left out of GLOBAL-DETECTOR. 


\section{GENERAL DESCRIPTION OF GLOBAL-DETECTOR}

The analysis and diagnosis of the economical performance on a dairy farm can be carried out by the knowledge-based computer system GLOBAL-DETECTOR (GLOBAL Discursive Expert for the Technical and Economical Control, Testing and Opinion-formation of Results), developed at the LEI in 1990. This system, which must be consulted with a microcomputer (PC), is intentionally meant as a tool for supporting farm management. However, it may also possess an educational value for farmers, advisors and students.

GLOBAL-DETECTOR consists of two parts: analysis and diagnosis'. The system analyses the accounting-data from bookkeeping reports, taking in it's scope all aspects of the gross-margin. The results from the analysis are presented in graphs, tables, overviews, texts and lists and are joined up with the relevant explanation. Analysis may be followed by knowledge-based diagnosis. Expertise in this part is necessary, since it requires integral judgement.

The analysis and diagnosis is globally executed; only the most important data are used. Detailed analysis and diagnosis certainly produces better results, but by doing so the system would grow to an unmanageable magnitude caused by combinatorial explosion. The objective of GLOBALDETECTOR is to present the dairy farmer the strong and weak aspects of the farm management in a "quick and easy" manner and to give advice for improvement of the tactical decisions of the farm management.

A prerequisite for a proper use of such system is that the farmer must have a good idea of the way how the system operates and comes to its conclusions. This is important in order to increase the farmer's insight in his farm, to improve his knowledge and management capabilities, and to increase acceptance of the system. The explanatory facilities of GLOBAL-DETECTOR are therefore crucial.

It should also be evident that the system is made as user-friendly as possible, since computernovices must be able to work with the system without any troubles.

\footnotetext{
"In the Netherlands the method "Information Engincering" is used in all brenches of agriculture to describe relationships between decision processes and information requirements (Zechariasse, 19906; De Hoop. 1988; Poppe, 1991b). The LEI has taken part in the identification of common dala requirements and decision processes across firms. Among other things, this led the detnilod Information Model of the cluster "Analysis and Dingnosis": A delailed description of how firescial farm detu can be anslysed to gain an impression of strong and weak aspects of the manigement (LEIVLB, 1989).
} 


\section{TECHNICAL SPECIFICATION}

In nearly all cases special computer programs called "shells" or "tools" can be used for building up expert systems as well as the exploitation of knowledge. There are numerous commercially available software packages, which can speed up the development of expert systems. However, the analysis part of GLOBAL-DETECTOR is the major part and this part does not need software suitable for expert systems. The use of a "shell" in combination with this software, will undoubtedly be a heavy burden on the memory capacity of the microcomputer. On the other hand, the diagnosis part needs expert system's software. But a "shell" for the diagnosis part is not used for some reasons:

1. A "shell" in combination with the more conventional software for the analysis part gives problems with the intemal memory of the computer. This disadvantage became visible during the development of an earlier expert system at the LEI (Hennen, 1989).

2. Most "shells" lack the flexibility necessary for such a hybrid system as GLOBALDETECTOR. The many functions this system possesses and bearing in mind some future developments, a flexibel programming environment is inevitable.

3. Software or a "shell" capable of implementing and using knowledge acquired by the method IMAGINE ${ }^{3}$, is not existing.

4. Users may have to pay a large amount of money for the royalties of the "shell", or must even purchase an expensive "shell" to consult the expert system.

Like the expen system decribed by Evans et al. (1989), GLOBAL-DETECTOR is also developed "from scratch", which makes use of an Artificial Intelligence's language. This language, muLISP (Soft Warehouse), is a dialect of the standard language Common LISP (Steele, 1984). muLISP consumes only a small amount of memory and is relatively fast. For all functions of GLOBALDETECTOR, software is developed in muLISP, i.e. software for user-interface; for calculation of standards; for making tables, graphs and bar-diagrams; as well as explanation-facilities; for the application of IMAGINE and the inferring of advices. No additional software packages are used. In anticipation of future developments, an inference engine ${ }^{4}$ for backward- and forward chaining is also programmed and may be added to GLOBAL-DETECTOR in due course.

\footnotetext{
'IMAGNE will be described later on in this paper.

4An inference engine is part of a knowledge-based systen ox expert system that contuins the general problem-solving knowledge. This inference engine processes the domain knowledge (located in the knowiedge base) to attain new conclusions (Waterman, 1985).

'Backward chaining is an inference method where the system starts with what it wants to prove and tries to establish the facts which are needed to prove the conjecture. Forward chaining is an inference method where the premisses of the "IF...THEN" rules are matched against facts to establish new facts (Waterman, 1985).
} 
All software for control, inferences, graphical output etc. have been programmed domainindependent, which means that the system can be used as a "tool" or "shell" for developing similar systems in other domains, even outside agriculture.

GLOBAL-DETECTOR can be consulted on a IBM PC or compatible computer. A hard-disk is recommendable. About $400 \mathrm{kByte}$ of intemal- and about $350 \mathrm{kByte}$ of external memory will be sufficient. These modest requirements make it possible to use this system on a large scale.

\section{THE ANALYSIS PART}

\section{Different methods for analysis}

Analysis is necessary for providing insight into the strong - and weak parts of the farm (Dobbins, 1988) and is therefore the focal point of any record-keeping activity (James and Stoneberg, 1986). Generally, analysing management practices can be done by using:

- averages of a group of comparable farms (external comparison);

- farm-inherent standards (internal comparison);

- historical farm-data (internal comparison).

External comparison is a method which, although easy to apply, has the difficulty of defining the comparable groups and the diversity within a group, since farms differ in many aspects. Farm-inherent standards are used for internal comparison and can be the result of planning or normative calculations. They are often used in management-information systems. Historical farmdata are useful for detecting trends, but they fail to show the relative position of a particular farm with respect to other farms.

In GLOBAL-DETECTOR, farm-adjusted standards have been used. These "hybrid" standards are in fact combinations of external and internal standards. Farm-adjusted standards have been developed and described by De Haan (1991). Data from more than 300 specialized Dutch dairy farms (random selected) were used to calculate algorithms by means of regression analysis. This resulted in separate algorithms for nearly all returns and variable costs. Each algorithm has an inherent set of independent variables and can be used to calculate a farm-adjusted standard for that particular aspect. The farm's actual values of the independent variables may be placed in that algorithm, followed by the calculation of the farm-adjusted standard value. This value may 
be considered as the value of an average Dutch farm for that particular aspect, while this average farm has the same values of independent variables as the farm under consideration. Farm-adjusted values can be compared with the actual values. Deviations might be an indication of bad performance.

Algorithms for the calculation of farm-adjusted standards are developed for each distinct year. These algorithms are therefore year-dependent. For a particular aspect, farm-adjusted standard values can be calculated in a couple of years. Comparing these values for that aspect in those years with the comparable actual values may result in different deviations in the distinct years. Detection of trends - based on these historical farm-data - can be carried out by GLOBALDETECTOR.

Farm-adjusted standards derived from empirical material are not meant as a goal or target. They are merely corrected averages. For example, according to the Dutch extension service the amount of concentrates fed are too high on most farms, mostly resulting in high costs. The cost on an average Dutch farm will therefore also be too high, which means that the farm-adjusted standard may not be used as a target value. However, with this standard value for the cost of concentrates, the farmer knows his position in relation to other farms.

The standards can indirectly be used as a goal in two ways. For some aspects, algorithms were also developed for the $25 \%$ highest and the $25 \%$ lowest performing farms with relation to that particular aspect. For a certain farm, the $25 \%$ highest standard for a return-aspect or the $25 \%$ lowest standard for a cost-aspect can be the goal to achieve. The second way is to let an expert make use of the deviation and other relevent data to elicit advices as to what actions the farmer can take to procure a certain goal. This is the advice-part of GLOBAL-DETECTOR, which will be explained later on.

\section{Results from the analysis part}

The farmer or advisor may use GLOBAL-DETECTOR to carry out the analysis. After having started the system, the bookkeeping-data from a chosen year are read in from a disk, which is followed up by the calculation of farm-adjusted standand values and other relevant variables. Then series of possibilities appear on the display which can be used to select the specific information the user wishes to go into. The menu-structure appears to be user-friendly. An overview of the realised and farm-adjusted standard values of all returns and variable costs, which are part of the gross-margin, is displayed in Fig. 1. Deviations are also given; favourable ones are indicated by , whereas unfavourable ones are indicated by !. All aspects are expressed 
in the same reference: guilders per hectare. This is a justifiable point of view, since it might be expected that the milk quota per hectare will not change in the short term on one particular farm and farmers aim at milking their full quota at the lowest costs as possible (De Hoop et al., 1988). The milk quota per hectare is thus one of the most important facts on a Dutch dairy farm.

The user might also be interested how an aspect is affected by an independent variable. A few dozens of graphs are at his disposal. One example is the influence of the milk production per cow (corrected for the percentage of fat and protein) on the gross-margin per hectare (Fig. 2). All other independent variables are kept constant. In the traject from 5000 to $10000 \mathrm{~kg}$ milk, the milk quota per hectare is also kept constant. This means that the number of cows per ha has to decrease when the milk yield per cow increases. It is obvious from the graph that for this particular farm the farm-adjusted standard for gross-margin will not always increase when the milk production per cow increases. Very high milk productions, e.g. more than $9,000 \mathrm{~kg}$, seem to be unfavourable for this farm, mainly due to low cattle-credits, the high costs for purchasing concentrates at such a high level and the rather low milk quota per ha. At that high milk yield per cow, the stocking rate is low and there will be a surplus of own roughage. Daatselaar (1988) came to comparable conclusions in his research.

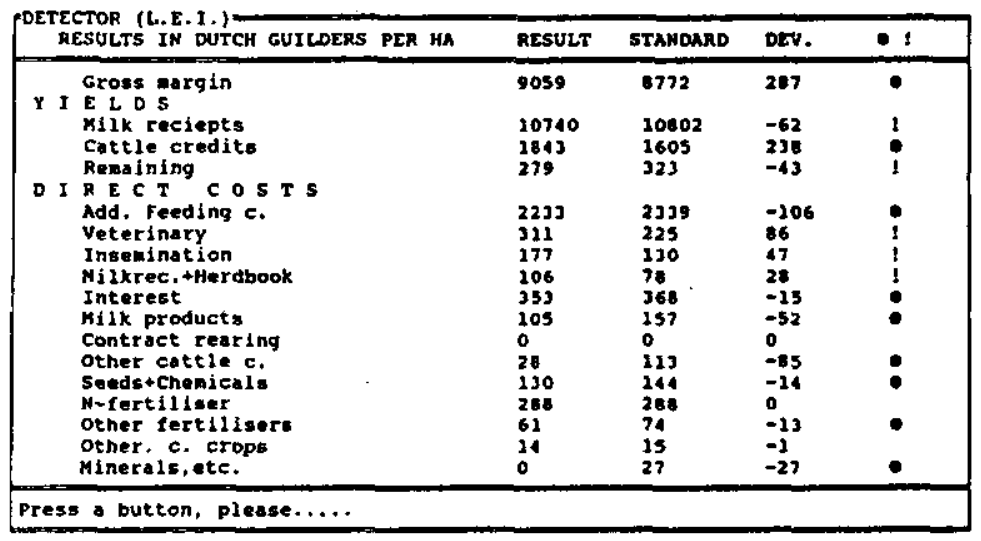

Fig. 1. Realised values, standard values and deviations for gross-margin, returns and variable costs. Output from GLOBAL-DETECTOR. 


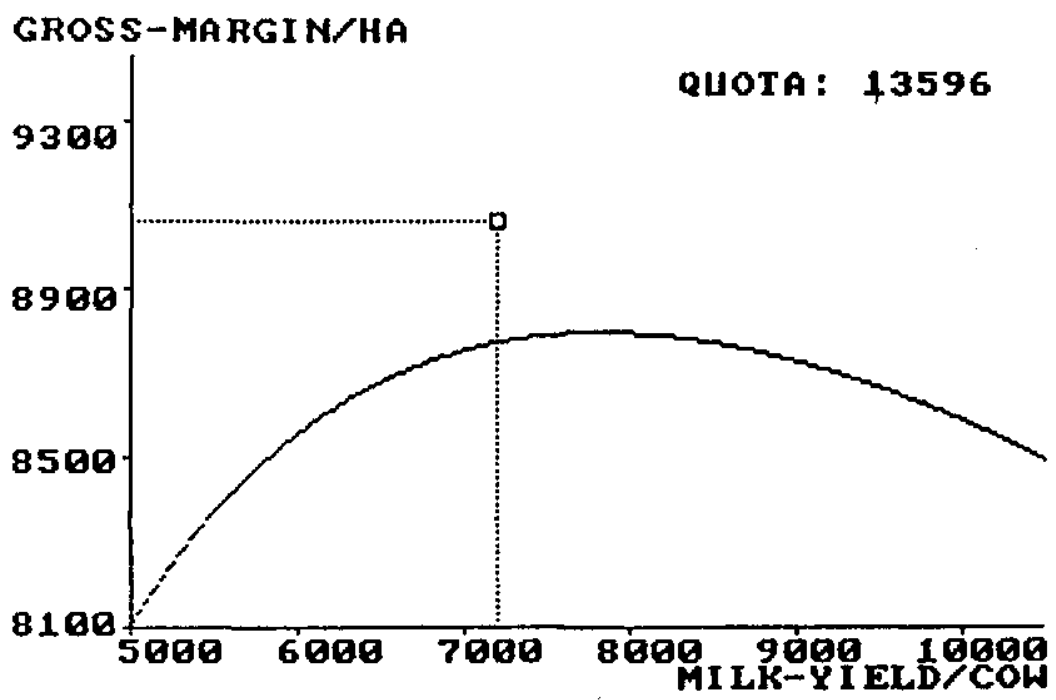

Fig. 2. Relation between the milk production per cow (X-axis) and the gross-margin per hectare ( $Y$-axis); and the position of farm $x$ having a milk qouta of $13596 \mathrm{~kg}$ per ha. Output from GLOBAL-DETECTOR.

The farm under consideration, displayed by a small block in Fig. 2, has not only realized a favourable gross-margin, but the milk production nearly reached an "optimal" level. Although not shown, each graph is accompanied by the necessary information.

As indicated before, some graphs do not only display average lines, but also lines for the highest and the lowest performing 25\% percent of the farms for that aspect. Fig. 3 displays the influence of the corrected milk production per cow on the cattle-credits per cow. The upper line shows the farm-adjusted standard for the highest (or best) $25 \%$ of the farms corrected for the same independent variables. This farm is better than a comparable average farm, but has a worse performance than the average of the best quarter of farms. Reaching the highest standard may be a goal.

Although very informative for analysing, the dozen bar-diagrams and tables which can be displayed, will not be described in detail in this paper. The bar-diagrams are useful for a quick glance at a couple of related aspects to discover easily the favourable and unfavourable ones, e.g. components of feeding costs. Tables are useful to display quantitive information and results which cannot be displayed graphically. 
The user has the possibility to skip easily to another year for analysis. Data from that year are read in from the database. The calculations that follow are done by means of farm-adjusted standard and standard prices for that particular year. As far as a very recent year is concemed, and having no algorithms for farm-adjusted standards available at the moment, the most recent algorithms are used in combination with price-indices. Deriving algorithms by regression-analysis can only be done if the data from a great number of farms are available at that moment. It is also possible to ask GLOBAL-DETECTOR for an overview of three years in succession. Fig. 4 shows such an overview. Realised values as well as deviations from farm-adjusted standard values from all aspects are displayed over three years. Some simple heuristics are implemented to make a trend analysis of the data in this table. Results are displayed to the user. Finally, the user can ask for a display of the most striking features of the farm, combined with the way GLOBAL-DETECTOR has inferred these. The function of this overview is to give the farmer or an advisor a quick idea of some outranging data in order to pin-point them in the report at hand. This may be important for the identification of problems.

Algorithms for inferring the most striking features are derived from both descriptive statistics and plain heuristics from an expert. The displayed features are no strong or weak aspects, they are merely characteristics worth mentioning when an expert takes a quick glance at the report. Strong and weak aspects of the farm management are the result of the expert system in the diagnosis part of GLOBAL-DETECTOR. 


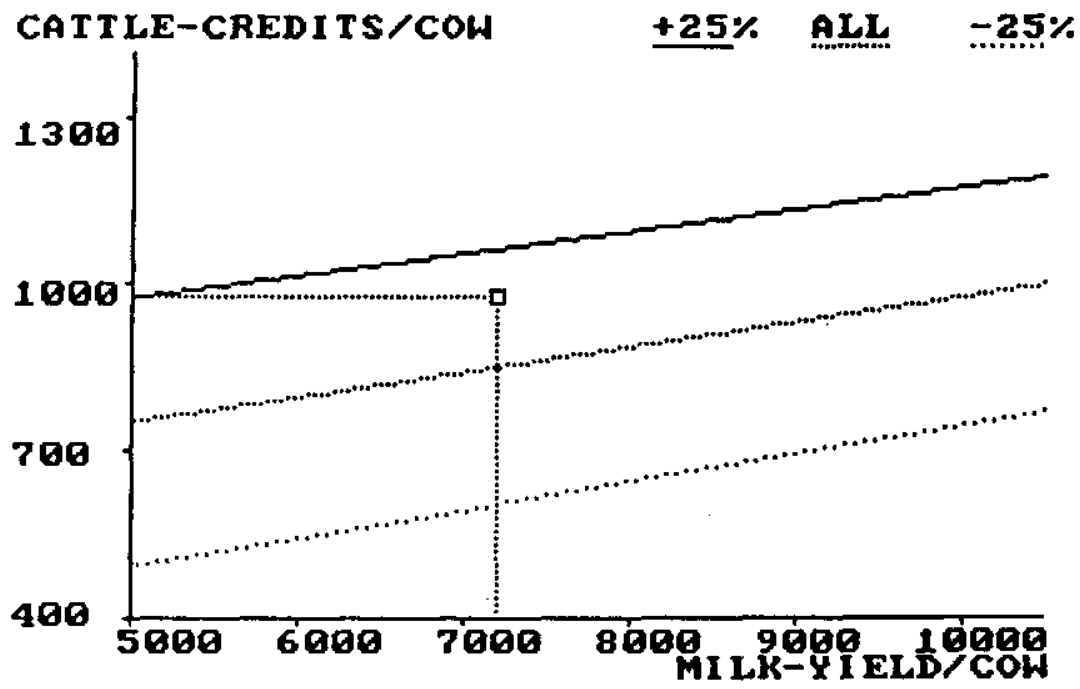

Fig. 3. Relation between the milk production per hectare $(\mathrm{X}$-axis) and the cattle-credits per cow ( $Y$-axis); and the position of farm $x$. Output from GLOBAL-DETECTOR.

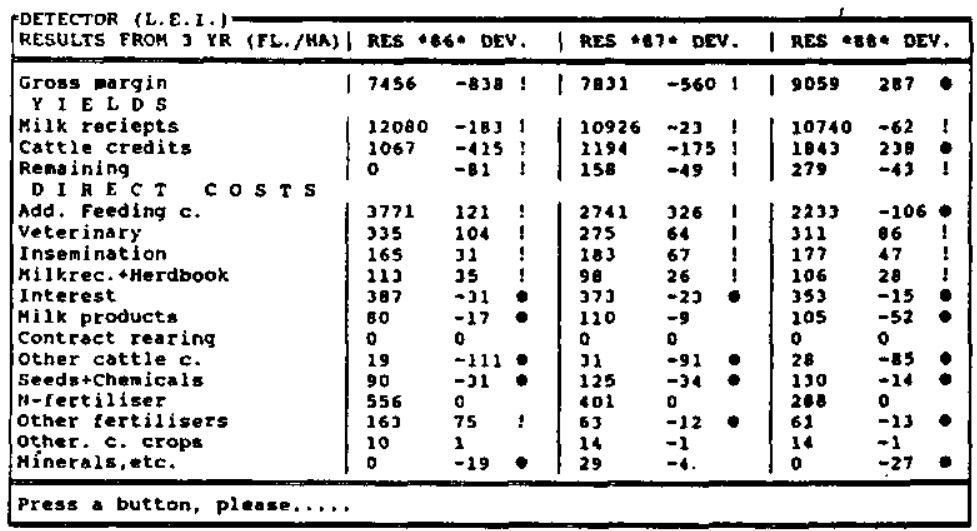

Fig. 4. Realised values and deviations from standards for gross-margin, returns and variable costs in three successive years. Output from GLOBAL-DETECTOR. 


\section{THE DIAGNOSIS PART (EXPERT SYSTEM)}

Negative deviations don't necessarily imply weak aspects. For example, a high cost factor may result in a high retum factor. Knowledge or expertise is indispensable for evaluating deviations in combination with other factors to make a sound diagnosis of the performance. Dobbins (1988) emphasizes the role of an "expert" for this task.

The objective of diagnosis is to find out what is wrong in the economical and/or technical sicuation of the farm (Longchamp et al., 1990) in order to provide the manager with information that will allow performance to be improved (Dobbins, 1988). The diagnosis part of GLOBALDETECTOR is therefore knowledge-based. To make things easier this part will be called an expert system ${ }^{6}$, because it's a computer program which uses the knowledge of one or more experts to solve problems in a specific field (e.g. Hayes-Roth et al., 1983). Since Evans et al. (1989) provide a fine overview of the structure and working of expert systems in an agricultural economics journal, this will therefore not be reviewed here.

\section{Knowledge acquisition with IMAGINE}

The analysis part was in the first instance used as a tool for acquiring knowledge. The expert consulted this part on 14 farms and wrote down his conclusions for each of them. These findings formed the basis for the development and application of a specific method for knowledge acquisition from experts: IMAGINE (Independent Method for Acquisition by Graphs and Implementation and Notification of Expertise).

Hennen (1991a) described and compared a dozen techniques for knowledge acquisition. This was done with special reference to agricultural economics. However, none could be used to handle combinatorial explosion, which seems to be a characteristic problem of the economic domain. This problem vanished with the application of IMAGINE.

The expert is asked to concentrate on a certain problem or conclusion (i.e. strong or weak aspect or advice) which may occur on an imaginative farm. After he has formed an image of this problem in his mind ("imagine"), he is requested to fill in a form which looks like a bargraph. On this form he has to write down the data or variables which are needed to infer if that particular problem exists. For each variable the level of importance and some boundaries have to

\footnotetext{
The authors are acquainted with the different definitions and the fact the the diagnosis part doesn't fit in some of them. Therefore the remarks of Evans et al (1989) are supponted in full by the authors: 'The term 'expert system' is often abused by those impressed with the implication of the phrase. In reality, seldom does a system reach - level of competence that is deserving of the tilie 'expert'. In this paper, in accordance with most of the available litereture, the name most ofien used will be 'expent system"".
} 
be indicated. These boundaries may be used to support, adjust and/or reject the strength of the conclusion. A score can be calculated for each variable, based on the level of importance, the values of the boundaries and the actual farm's value of that variable. The average score of all variables give the score or strength of that particular conclusion.

These forms may be filled in independent from the knowledge engineer (i.e. the builder of an expert system). The data on the form can very easily be stored in the knowledge base of GLOBAL-DETECTOR. Software has been developed by the LEI to present the expert's knowledge to the user, in combination with the relevant explanation and the way the conclusions are drawn.

It appeared during the development, that in this domain IMAGINE is a very useful method for knowledge acquisition. A more detailed description of IMAGINE will be presented in detail by Hennen (1991b).

\section{Results from the diagnosis part}

Still being in GLOBAL-DETECTOR, the user may skip from the analysis part to the diagnosis part, simply by chosing from the menu. The relevant conclusions, i.e. strong and weak aspects and advices, appear on the screen (Fig. 5). As can be seen, each of these performance judgements are summarized in only a mere handful of remarks. Each judgement is quantified in a score or strength, and that enables to discriminate between judgements. All conclusions are presented on their importance. The most important, having the highest score, is displayed first. Each conclusion is additionally be accompanied with it's certainty factor.

Conclusions which may be less obvious, as well as irrelevant findings, are displayed separately. Extensive information about how the expert has reached to this conclusions can be retrieved by the user. The displays show the user the necessary information. One part of the information is an easy readable text about how the expert generally came to such conclusion. This serves as background information. The other part of this information, which the user also gets displayed on the screen, is a bar-graph (Fig. 6) which is almost identical with the form the expert has filled in during knowledge acquisition. The only difference is the supplementing with farm-data and the calculated score of the conclusion. In Fig. 6 this explanation is presented. The conclusion, in this case an advice, is provided with a moderate to high positive score. This means that there is evidence for it's truth on this farm. According to the expert, two variables 
determine the strength of that advice: the deviation between actual and standard value for cattlecredits and the deviation between the actual and the standard value for total amount of purchased feed. Both deviations (-176 and 72.5 respectively) support the advice since they are on the right side of the bar-graph. After calculation, the scores for cattle-credits and purchased feed seem to be +3.5 and +1.2 respectively, resulting in an average score of 2.35 for the advice.

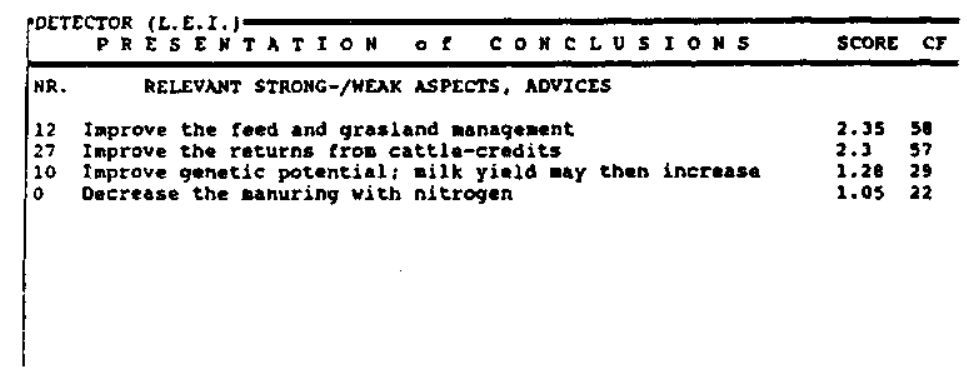

Fig. 5. The most important conclusions from a particular farm. Output from GLOBALDETECTOR.

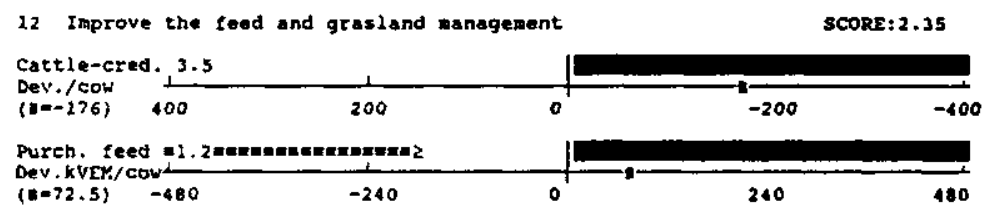

Fig. 6. Presentation of an advice with the IMAGINE method. Output from GLOBALDETECTOR.

The user may retrieve more detailed information of this method by means of a programmed help-facility.

Due to the global feature, many advices from GLOBAL-DETECTOR have a medium- or longterm characteristic, e.g. increase milk production, improve commercial management or purchase of land with a high milk quota. They mainly support tactical decisions of a farmer.

Implementation of these advices can take considerable time and may have a medium- or longterm effect on the farm's structure and management, eventually - and hopefully - resulting in an inrease in income or profitability. In this perspective, the advice part may support management with an economic goal of the farmer. 


\section{EVALUATION OF GLOBAL-DETECTOR}

A paper of De Gier (1990) describes in detail the favourable changes on a Dutch farm due to right managerial decisions over a couple of years. The data from this farm were also analysed by GLOBAL-DETECTOR, and it was striking to see that comparable advises were given by GLOBAL-DETECTOR (Hennen and De Hoop, 1991). From this comparison, Hennen and De Hoop conclude that this computer program can signal main striking points and give directions for improving the farm-performance in the future. The farmer, with or without his advisor, can use this outcome as a starting point for further detailed analysis to detect the main causes and to take the necessary actions.

At the moment the system is being tested in some accounting-offices to be able to find out whether the system can be used in their organisation. No test-results are available yet, but members of these offices voiced the need of such a system.

GLOBAL-DETECTOR will also be placed on the microcomputers in a couple of farms in January 1991. At the same time, this system will be integrated with the Farm Accounting Data Network (FADN) of the LEI.

\section{FURTHER RESEARCH}

GLOBAL-DETECTOR will be validated by one or more experts and be tested in practice. After that, a further (detailed) elaboration of the conclusions may be executed and implemented in the system. A perspective is also an extension with the fixed costs and an analysis and diagnosis of the financial structure. With these augmentations, we wish to hand the dairy farmer a system for supporting integral management.

The system's objective is also to serve research purposes, in particular the investigation of differences in management in relation to the farmer's income. Especially self-criticism is a major point of view, since ".... the farmer's willingness to criticize his own decisions and actions and to continue learning are fundamental in keeping the enterprise profitable." (Zachariasse, 1974). This research will be done after the system has been validated and thoroughly tested. The interaction with other systems (e.g. causal networks, tactical planning systems, systems for optimization, neural networks, etc.) will also be an objective for the future in order to develop more integrated management information systems for Dutch dairy farms. 


\section{DISCUSSION}

GLOBAL-DETECTOR is a knowledge-based computer system for supporting management on dairy farms. However, on dairy farms there are not only differences in farm-structure, but also manager's differences in information and decision behaviour (Bemelmans, 1987). This is mainly caused by a distinction in the farmer's goals and his willingness to criticize and leam (Zachariasse, 1990a). Farmers possess numerous goals, like maximize profit or return, increase net worth, avoid losses, increase leisure time, have a neat and well-kept farmstead, etc., and these goals may change over the life cycle of the individual (Boehlje and Eidman, 1984). Due to differences in information, decision behaviour and goals, each individual farmer has a specific need for information (De Hoop et al., 1988) and this individuality will certainly result in various levels of appreciation and use of the system. Roep et al. (1991) came to such conclusions, after interviewing 104 dairy farmers who use a program for analysing feeding costs (DELAR).

Each farmer has specific wishes and demands and it is therefore a difficult task to develop management information systems that will be used on large scale (De Hoop et al., 1988). It should be obvious that Dutch farms are too small (as contrasted with industries) to develop an information system for each or for a small group. So it is an arduous task to supply them with systems which match their individual goals completely and as a result support their individual management satisfactory. It should therefore not be too surprising to see that GLOBALDETECTOR does not match up with the individual wishes and demands. However, an optional framework has been implemented in GLOBAL-DETECTOR to meet this problem halfway. Further investigations will show if the optional approach is preferabe. Due to the global character of the system and as a result mere indications of good or bad performance, individual differences in management mainly play a role in the detailed analyses on the farm itself done by the farmer and/or his advisor. GLOBAL-DETECTOR may therefore be more general. The very flexible programming environment which has been used during the development of GLOBALDETECTOR (muLISP), allows rapid modifications when this seems necessary. Specific wishes can then be met rather easy.

GLOBAL-DETECTOR obtains data from the LEI-database, without a manual data entry. When integrating the system with databases from other organisations or with a farmer's database, the same data should be used. In the Netherlands, Information Models were being developed for all branches of agriculture (Poppe, 19916; Zachariasse, 1990b). In these models data-definitions were harmonised and described. Although Information Models seem to have a positive impact on 
the adoption of information technology in Dutch agriculture, the use of uniform data by the different organisations has not been fulfilled yet. Integration of GLOBAL-DETECTOR with other databases requires therefore a thorough investigation of the available data from these databases. After knowing how the data are defined, some precalculations and a number of adjustments of the system might be necessary before instailation.

The knowledge-based approach is inevitable in the diagnosis part, as indicated before. By means of proper explanation facilities, the farmer may have access to the knowledge which might be new to him. This possibility makes computerized expert system beneficial (Webster and Amos, 1987). The extension service may use such a systems for their specialists as an aid or as an intelligent assistant, to increase the knowledge in complex areas, and to give uniform advice (Hennen, 1989). On the other hand, the knowledge and skill available from dairy extension specialists may be used for developing expert systems that evaluate dairy herd and farm management data. There exists significant opportunities for this approach in the US (Smith, 1989).

The way conclusions are inferred in GLOBAL-DETECTOR are quite simple and easy to explain to the user. Due to this simplicity, the reliability of the outcome may be less than one should wish. In general, it should be clear that by increasing the reliability of a system, the acceptance by the user will also increase (Fig. 7).

The reliability may increase when taking into account probabilities, dependencies, certainties etc. or performing some kind of corrections. However, in this situation the expert may have too many difficulties to verbalize his knowledge. Even if this would be possible, the outcome should also be clear to the user. If too many corrections etc. are carried out in a such very reliable system, it may be too difficult for the user to understand. Decrease in understanding will lead to a decrease in confidence and undoubtedly lead to a decrease in acceptance. This is especially true for unstructured problems. Refering to Fig. 7, it must be our goal to have a system with such a great reliability that the acceptance will be maximal. With thorough explanations and/or very good support, the acceptance will be higher. A complexer - and through that a more reliable - system is then possible (dotted line in Fig. 7). This illustrates the importance of implementing explanation facilities in management information systems, which is also emphasized by Evans et al. (1989) who remark: "Without such an ability user confidence in a system will be understandably fleeting and the system simply will not be used.". 


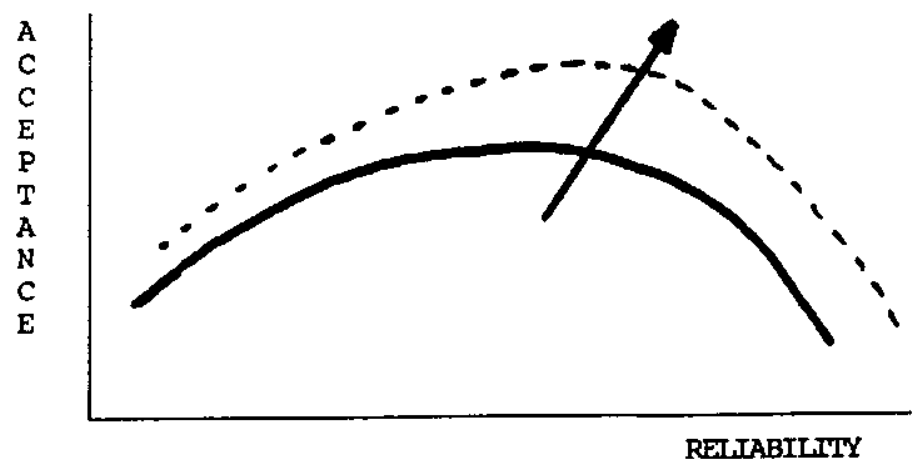

Fig. 7. The influence of reliability on acceptance for unstructured problems.

The drawing of conclusions of the performance was not only done in a very simple way, but also very shallowly or globally. The farm-data used were restricted to the most important data found in the bookkeeping database, comparable with the "quick and easy" approach in the expert system FinARS (Boggess et al., 1989). This limitation can lead to wrong judgements, because we don't possess all the necessary and detailed information to be highly accurate. However, it is our objective to be as reliable as possible with only a few data at our disposal. A larger amount of data might lead to an unmanagable domain. It should be clear in the presentation that the drawn conclusions are strong evidences, but no absolute truths. It is the farmer's task, with or without an advisor, to take notice of the relevant conclusions. These can act as important signals to take the necessary actions, or as a starting point to carry out further detailed investigations with or without an advisor or computerprogram. Farmers don't expect that information systems give the ultimate answer, but want to use these systems for support, that is gaining more insight in the aspects of decision-making, in the rationale of algorithms and in the direction of the outcome (De Hoop et al., 1988). This should stimulate the dairy farmers in their creativity. A system which is prescriptive instead of informative is therefore not desirable. The farmer must take the ultimate decisions, and it's our task to provide the appropriate tools to support these decisions. 


\section{REFERENCES}

Alleblas, J.T.W. Management in de glastuinbouw, cen zaak van passen en meten. Thesis. Den Haag, LEI, 1988. (English summary).

Battc, M.T., G.D. Scbnikkey and E. Jones. "Sources and uses of farm management information findings from the Ohio State University survey." In: R.P. King ed.: Future directions for farm information systems research. St. Paul, Agricultural Experiment Station University of Minnesota, $1990 \mathrm{~b}$.

Bemelmans, T.M.A. Bestuurlijke informatiesystemen en automatisering. Leiden, Stenfen Krocse, 1987.

Bochlje M.D. and V.R. Eidmar. Farm Managenent. New York, etc., John Wilcy \& Sons, 1984

Boggess, W.G., P.J. van Blokland and S.D. Moss. FinARS: A Financial Analysis Revicw Expert System. Agr. Systcms 31(1989), pp 19-34.

Brand, A., J.H.M. Verheijden, D.S. Bréc, J.F. Schreinemakers, J.A. Renkema and L.C. Zachariassc. ANIMAL FARM. An intelligent knowiedge-based computer system for integral management in animal husbandry. Rotterdam, Erasmus University, Management Repont Scric No. 11, 1986.

Brée, D.S. and W.H.G.J. Hennen. "The use of expert systems for the interpretation of technical and economical performance of dairy farms." In: G. Schicfer ed.: Expertensysteme in der Agrarwirtschaft: Entwicklung, Erfahrung. Perspektiven. BRD, Vauk Kicl, 1989.

Daatselaar, C.H.G. De invioed van de melkgift op het saldo per ha. Den Hagg, LEI, 1988.

Dobbins, C.L. A revicw of farm business analysis rescarch. USA, University of Minnesota, Draft 2.2, 1988.

Dobbins, C.L. and R.P. King. An expert system for interpreting the year-end business summary of crop-hog farms. USA, University of Minnesota, Draft 2, 1988.

Evans, M., R. Mondor and D. Flaten. Expert Systems and Farm Management. Can. J. Agr. Ec. 37(1989), pp 639666.

Gier, JJ. de. Eight years Nitrogen Pilot Farm A.A.W. Theunissen. Meststoffen 3, 1990.

Haan, T. de. Het ontwikkelen van bedrijfsspecifieke vergelijkingsmaatstaven roor de analyse van het bedrijfsresultaat op melkvecbodrijven. Den Haag, LEI, 1991. (submitted).

Harsh, S.B., R. Brook, R. Harmon. "AIMS - Agriculural Integrated Management Softwarc." Proceedings of the 3rd international DLG-Congress for computer technology on Integrated Decision Support Systems in Agriculture. BRD, Frankfurt a.M., 1990.

Hayes-Roth, F., D.A. Watcrman and D.B. Lenat [cds]: Building Expert Systems. Wokingham, England etc., AddisonWeslcy Publishing Company, 1983.

Hennen, W.H.GJ. De methode voor het bouwen van expert systemen: Getest voor de analyse van de omzet op melkvcebedrijven. LEI, Den Haag, 1989.

Hennen, W.H.GJ. Elicitatie-technieken. Mogelijkheden en beperkingen voor de ontwikkeling van de GLOBALDETECTOR en de modules van het MPP-project Den Haag, LEI, 1991a. (in preparation).

Hennen, W.H.G.J. IMAGINE: Acquisition, representation and presentation of cconomical performance inowledge. Den Haag, LEI, 1991b. (in preparation).

Hennen, W.H.GJ, and D.W. de Hoop. Een computermatige kijk op het stikstofproefbedrijf van A.A.W. Theunissen. Meststoffen, 1991 (?) (submitted).

Hoop, D.W. de, J. Engelsma, GJ. Wisselink. De tactische boer, het management en de informatiebehoefte van melkvechouders. Den Haag, LEI, 1988.

James, S.C. and E. Stoncberg. Farm Accounting and Business Analysis. Ames: Iowa State University Press, 1986. 
King, R.P. and S.T. Sonka. "Management Problems of Farms and Agricultural Firms." In: R.J. Hildreth, K.L. Lipton, K.C. Clayın, C.C. O'Connor [eds]: Agriculture and rural areas approaching the twenty-first century; Challenges for Agriculural Economics. Iowa, Lowa Statc University Press, 1988.

King, R.P., S.B. Harsh and C.L. Dobbins. Farm information systems: farmer noeds and system design strategies. TSL, 5(1990)1, pp 34-59.

LEIVLB. Gedelaileerd informatiemodel "analyse en diagnose". Den Haag/Leiden, LEL/VLB, 1989.

Longchamp, J.Y., J.P. Nicoletti and L. Lescar. "A Coherent set of Decision Support Software for Farm Management." Proceedings of the 3rd international DLG-Congress for computer technology on Integrated Docision Support Systems in Agriculture. BRD, Frankfurt a.M., 1990.

McGrann, J.M., K. Karkosh and C. Osborne. Agricultural Financial Analysis Expert Systems: Software Description. Can. J. Agr. Ec. 37(1989), pp 695-708.

Morahan, A.G., DJ. Ruane and M. Butler. "The development and evaluation of a microcomputer based management information system for a dairying enterprise." In: Dodd and Grace [eds]: Land and Water Use. Balkerna, Rotterdam, 1989.

Phillips, J.J. and S.B. Harsh. "An Expert System Application to the Financial Analysis of Lender Case Farm Records." Paper presented at AAEA annual meeting. Lansing, Michigan, 1987.

Poppe, KJ. Van bedrijfsuitkomsten tot financielle positic (BEF). Samenvattend overzicht van landbouwbedrijven tor en met 1984/1985. Den Haag, LEI, 1986.

Poppe, K.J. "Using farm accounts: a survey and rocommendations for further research." In: K.J. Poppe ed.: Information nocds and accounting in agriculture. Den Haag, LEI, 19912. (in press).

Poppe, KJ. "Determining farmers' financial informalion requirements." In: KJ. Poppe ed.: Information needs and accounting in agriculture. Den Haag, LEI, 1991b. (in press).

Rocp, D., J.D. van der Plocg and C. Leeuwis. Zicht op duurzaamheid en kontinunteit, bedrijfsstijlen in de Achterhock. LUW, vakgr. Agr. Ontwikkclingssociologic, Wageningen, 1991.

Smith, T.R. The Potential Application of Expert Systems in Dairy Extension Education. J. Dairy Sci 72(1989), pp 2760-2766.

Stecle, G.L. Ir. Common LISP: The Language. USA, Digital Press, 1984.

Waterman, D.A. A guide to Expert Systems. Reading, etc., Addison-Wesley Publishing Company, 1985.

Webster, J.P.G. and J.J. Amos. Expert systems for agricultural management. Farm Management 24, 1987

Zachariasse, L.C. Farmer and Farm returns. An analysis of causes of differences in profitability of similar arable farms in the North-East-Polder. Thesis, Wageningen, 1974. (English summary).

Zachariasse, L.C. Managementcapacileiten: elementen en beinvloeding. In: Bureau PHLO [eds]: Achtergrond en gebruik van economische modellen en expertsystemen ter ondersteuning van management-beslissingen op melkveeen varkensbedrijven. PHLO, Wageningen, 1990a.

Zachariasse, L.C. "Farm management information systems planning and development in the Netherlands." In: R.P. King ed.: Future directions for farm information systems research, St. Paul, Agricultural Experiment Station University of Minnesota, 1990b. 